\title{
FILOSOFIA DA DIFERENÇA E A QUESTÃO POLÍTICA DA IDENTIDADE RACIAL
}

\author{
Matheus Barbosa Rodrigues ${ }^{1}$
}

Resumo: O presente artigo investiga a relação entre a filosofia da diferença de Gilles Deleuze e a questão política da identidade racial. Em um primeiro momento, desenvolvemos a crítica da filosofia da diferença em biologia ao conceito de raça. Em seguida, com base em Achille Mbembe, demonstramos como fenômenos do mundo contemporâneo, a despeito da negação de fundamentos biológicos de discriminação, reorganizam-se ao longo de hierarquias racialmente determinadas. A partir daqui, visando o caso particular do Brasil, defendemos que a aposta na filosofia como porta voz de uma igualdade superior, sem o saber e à sua revelia, traduz uma posição política regressiva, isto é, induz à reafirmação do valor positivo depositado no mito da democracia racial. Por fim, buscamos apontar as direções iniciais para um reajuste das relações da filosofia da diferença com a questão racial. Palavras-chave: diferença - identidade - raça - Deleuze - Mbembe.

\section{INTRODUÇÃO}

Em toda sua obra, o filósofo Gilles Deleuze nunca se debruçou diretamente sobre a questão racial negra. Nas vezes que se aproximou do tema, a raça e o racismo aparecem como caso mais geral de um delírio social, histórico e político de todos os povos. ${ }^{2}$ Sobre a diáspora, colonialismo e escravidão da população negra, contudo, Deleuze nada escreveu.

\footnotetext{
${ }^{1}$ Mestrando em Filosofia pela Universidade Federal de São Paulo (UNIFESP). São Paulo, SP, Brasil. Contato: matheus_b_rodrigues@hotmail.com. Orientador: Dr. Sandro Kobol Fornazari. Pesquisa financiada pela FAPESP e CAPES, processo n 2018/06360-2, Fundação de Amparo à Pesquisa do Estado de São Paulo. As opiniões, hipóteses e conclusões ou recomendações expressas neste material são de responsabilidade do autor e não necessariamente refletem a visão da FAPESP ou da CAPES.

2 Junto com Félix Guattari, em "O Anti-Édipo" Deleuze defende que o "delírio racial” não funda apenas uma ficção ou é racista necessariamente, mas caracteriza-se como uma invenção de povos e culturas que inscrevese no real ao longo da história universal: "todo delírio tem um conteúdo histórico-mundial, político, racial; arrasta e mistura raças, culturas, continentes, reinos” (DELEUZE E GUATTARI, O Anti-Édipo, p. 123). Mesma chave retomada outras vezes por Deleuze como, por exemplo, em "Literatura e a Vida": "não há delírio que não passe pelos povos, pelas raças e tribos, e que não ocupe a história universal” (DELEUZE, “A literatura e a vida", Crítica e Clinica, p. 15).
} 
No que pese o relativo desinteresse de Deleuze pelo tema, poderíamos argumentar que sua filosofia oferece ferramentas para uma reflexão acerca da questão racial, bem como das relações de gênero, de homossexualidade, drogas e esquizofrenia. $\mathrm{Na}$ maioria das vezes, as lutas minoritárias são pensadas na chave das identidades, da representação e do reconhecimento. De uma perspectiva deleuziana, porém, a lógica que sustenta essa postura política poderia ser problematizada. Para não sermos coniventes com as estruturas que combatemos, antes seria necessário resistir dentro de uma lógica da diferença, do devir e do molecular. Acompanhando Deleuze, poderíamos dizer que nos "devires-minoritários" não se trata de determinar uma identidade, lugar de fala ou expressão dominante nova, mas, isso sim, de dissolver toda e qualquer hierarquia: "encontrar a zona de vizinhança, de indiscernibilidade ou de indiferenciação tal que já não seja possível distinguir-se de uma mulher, de um animal ou de uma molécula"3.

O mesmo raciocínio valeria para pensar a questão política da identidade racial. Em nome de uma igualdade mais profunda entre os seres, a filosofia opõe à identidade a gramática de uma universalidade ampliada. Resta-nos perguntar: qual a pertinência desta “aplicação", especialmente em contextos pós-coloniais? Quais os efeitos políticos dessa operação em territórios como o brasileiro?

No presente artigo, exploramos a hipótese de que ao silenciar sobre premissas do colonialismo e da escravidão, sem o saber e à sua revelia, a máquina conceitual deleuziana mobiliza uma posição política conservadora. Da perspectiva das tensões sócio históricas envolvidas na identidade racial, a aposta na filosofia como porta-voz de uma igualdade superior se alinharia com uma postura regressiva, isto é, se comprometeria com a versão racista da "ideologia pós-racial".

Em um primeiro momento, buscamos expor brevemente o que entendemos por filosofia da diferença. Em seguida, desdobramos algumas consequências de suas proposições, sobretudo no que diz respeito à relação entre a biologia molecular e a questão política das identidades. Por fim, colocamos em xeque o deslocamento da lógica da diferença com o intuito de pensar a identidade racial. Mais do que recusar a filosofia de Deleuze, espera-se, com isso, propor as direções para um reajuste das suas relações com a questão racial.

\section{A FILOSOFIA COMO FORMA SUPERIOR DE IGUALDADE}

Em suas linhas mais especulativas, a filosofia da diferença caracteriza-se como o esforço de conciliar um mundo de diferenças e devires com a realidade substancial do Ser. Trata-se de um problema tão antigo quanto a própria filosofia, de Parmênides a Heidegger, de Heráclito a Nietzsche: de um lado o Ser Uno e imutável, do outro o devir incessante do rio que nunca é o mesmo. Qual princípio prevalece? É possível reuni-los?

Apesar deste tema acompanhar Deleuze a vida toda, ele está presente de maneira enfática e exemplar em seu doutorado, Diferença e Repetição (1968). Notadamente no primeiro capítulo, Deleuze pensa a ontologia através da história da submissão da diferença às

${ }^{3}$ Ibid. p. 11. 
exigências da representação e da identidade. Para fins introdutórios, fiquemos com o significado geral da tese deleuziana: a subversão do platonismo.

De acordo com Deleuze, a filosofia da representação, tanto a antiga quanto a moderna, deve seu princípio ao esquema platônico de submissão da diferença à identidade. Com sua dialética, Platão cria um método de seleção entre os verdadeiros e os falsos pretendentes. Os pretendentes são avaliados segundo uma ordem de participação eletiva, isto é, segundo a medida ontológica fornecida pelo mito. No diálogo Político, o mito do Deus que comanda os homens no período arcaico estabelece o modelo do "Rei-pastor dos homens". Pelo critério da semelhança, é possível afastar da ideia de político as más cópias: parentes, serventes, charlatões etc. Mesmo procedimento no Fedro: o mito da circulação das almas serve para Platão distinguir o verdadeiro do falso amante entre poetas, padres, adivinhos e filósofos.

Desse modo, Platão termina levantando a questão da diferença em termos morais, pois, contra a diversidade do mundo sensível, trata-se sempre de estabelecer hierarquias e fronteiras entre as boas e as más cópias, entre os bons e os maus pretendentes. Na visão de Deleuze, desde então, toda vez que a Filosofia se propôs a "salvar" a diferença foi sob o signo deste ranço moralista: de princípio e sem mais explicações, a diferença é tomada como faltosa e negativa. Em Aristóteles, Leibniz ou Hegel, de uma forma ou de outra, a história da Filosofia da representação se fez sempre sob o vínculo platônico. A cada vez, trata-se de repor um princípio superior em relação ao qual desdobra-se uma operação seletiva. Esta, por seu turno, condena tudo aquilo que não se assemelha ao modelo: o dessemelhante, o simulacro, a diferença em si.

Requalificar a diferença, então, passa por subverter a ordem de subordinação platônica. De maneira geral, o engano dos filósofos da representação seria o de pensar a diferença como oposição entre existências particulares, individualidades dadas ou predicados contrários. Limitado a isso, o pensamento só se reporta a existentes e indivíduos previamente identificados, ao mesmo tempo que não pode dizer o que constitui as individualidades antes de elas se formarem.

Em outras palavras, para a filosofia da representação a diferença pode ser pensada como relativa aos termos em oposição, mas nunca em si mesma, pois, neste caso, ela se confunde com o mero indiferenciado. No entanto, Deleuze acredita em uma terceira via: em si mesma, a diferença não é simplesmente matéria indiferente e sem representação, mas, mais profundamente, um princípio genético, completa ele, "que não é menos capaz de dissolver e destruir os indivíduos quanto de constituí-los temporariamente" . O filósofo da diferença não persegue nem o indiferenciado e nem o diferenciado, mas coloca no primeiro plano os processos de diferenciação, nunca pré-estabelecidos ou concluídos de uma vez por todas.

Do ponto de vista ontológico, importa relacionar o Ser com uma diferença que já não se faz entre indivíduos, representantes, gêneros ou espécies delimitadas. Ao contrário, afirma-se a soberania de diferenças, diz Deleuze, "que não se deixam reter nos limites

${ }^{4}$ DELEUZE, Diferença e Repetição, p. 100.

5 Ibid. p. 74. 


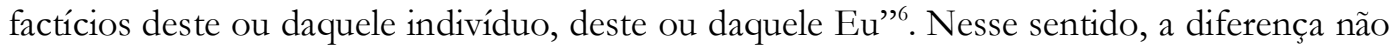
só se afasta por natureza da representação, mas antes e sobretudo

precede de direito a forma e a matéria, a espécie e as partes, e qualquer outro elemento do indivíduo constituído. Na medida em que se reporta imediatamente à diferença, a univocidade do ser exige que se mostre como a diferença individuante precede, no ser, as diferenças genéricas, específicas e mesmo individuais. ${ }^{7}$

Estamos no núcleo da argumentação deleuziana. Em sua dimensão propriamente genética, a diferença constitui-se como fundo que não aceita nenhuma hierarquia entre os seres existentes, seja entre homem e animal, corpo e alma, seres orgânicos ou inorgânicos. $\mathrm{Na}$ dimensão pré-individual da experiência não sobrevive nenhuma ordenação por semelhança a um princípio individual supremo. Em um mesmo plano imanente, todos participam imediatamente do Ser com igual dignidade ontológica, sem intermediários ou mediações: "Portanto, a univocidade do ser significa também a igualdade do ser".

É preciso entender com cautela a operação deleuziana. Ao contrário do que sustentam alguns de seus críticos, a univocidade do Ser não supõe nenhuma filosofia do Uno?. Para precisarmos o "comum" entre os seres, não nos voltamos para uma identidade superior, mas para a diferença como elemento individuante e genético de todas as coisas. Nesse sentido, a afirmação da diferença como matéria do Ser - e isto é o decisivo - está comprometida com uma operação de dissolução de hierarquias próprias ao mundo da representação, identidade e indivíduos. Seguimos Lapoujade aqui: a univocidade, diz ele, “(...) significa que não é mais possível estabelecer uma hierarquia entre pretendentes, distribui-los segundo séries eletivas como fazia Platão" ${ }^{\text {. }}$.

A univocidade do ser não supõe uma filosofia do Uno, mas, bem entendida, uma filosofia da igualdade. Nota-se: não se trata de simples jogo de palavras. No primeiro caso, o "comum" se ligaria com uma identidade acima das diferenças que se lhe assemelham. Assim, involuntariamente, Deleuze sucumbiria justamente àquilo que era criticado desde o início: o platonismo e seu modelo hierárquico de seleção. Ao ligar o ser à diferença, ao contrário, é a expressão de um igualitarismo radical o que está sendo posto em campo. Desta perspectiva que nos interessa, enfim, Deleuze pode conciliar o ser com o devir, o uno com o múltiplo: "Então, as palavras 'Tudo é igual' podem ressoar, mas como palavras alegres, com a condição de dizê-las do que não é igual neste Ser igual unívoco""

\footnotetext{
${ }^{6}$ Ibid. p. 74.

${ }^{7} \mathrm{Ibid}$. p. 70.

${ }^{8}$ Ibid. p. 69.

${ }^{9}$ Alain Badiou é sem dúvidas o caso mais célebre dessa crítica contra Deleuze: “Ora, ao contrário da imagem comum (Deleuze como liberação do múltiplo anárquico dos desejos e das errâncias), ao contrário mesmo de aparentes indicações da obra (...), é ao advento do Uno, renomeado por Deleuze como Uno-todo, que se consagra, na sua mais alta destinação, o pensamento" (BADIOU, Deleuz̧e - o clamor do Ser, p. 18).

${ }^{10}$ LAPOUJADE, Deleuze, os movimentos aberrantes, p. 57.

${ }^{11}$ DELEUZE, Diferença e Repetição, p. 68.
} 
Do ponto de vista da ontologia deleuziana, pode-se afirmar que a filosofia anda lado a lado com uma forma superior de igualdade. Ou ainda, como comenta Gualandi, a univocidade caracteriza-se como a "expressão intelectual do amor por tudo aquilo que existe"12. Enfim, desdobra-se daqui o programa mais geral da filosofia da diferença: para subverter o platonismo, Deleuze precisa construir um sistema de pensamento que não mais distribua os pretendentes em função de categorias, gêneros, espécies, hierarquias morais, teológicas ou epistemológicas. ${ }^{13}$

Para darmos traços mais concretos ao projeto deleuziano, investigaremos na sequência dois de seus desdobramentos: o encontro da filosofia da diferença com a biologia molecular e, seguindo-se diretamente deste, sua repercussão na questão política das identidades.

\section{LÓGICA DA DIFERENÇA EM BIOLOGIAE A QUESTÃO POLÍTICA DAS IDENTIDADES}

A genética nos dá um bom exemplo do sentido da subversão do platonismo. Baseandose sobretudo na repartição empírica das diferenças e semelhanças, até meados do século XX, os biólogos avaliavam os seres humanos com processos classificatórios racialmente determinados. À maneira platônica, estabelecia-se uma hierarquia das raças no processo evolutivo conforme a semelhança com um modelo. Entretanto, o desenvolvimento da genética pôs a legitimidade das antigas classificações em questão. Dito de maneira simples, passamos do mundo das representações táteis e visuais (características anatômicas, ósseas, cor de pele etc.) para o mundo microscópico das moléculas (mitocôndrias, cromossomos, genes etc.). Não é apenas o "tamanho" do dado analisado que muda desde então, mas toda a natureza e lógica das determinações biológicas.

Sob a lupa de Deleuze, a genética situa-se na zona pré-individual dos elementos diferenciais. Isso por duas razões: sua dimensão molecular é independente de um princípio de identidade e, em segundo lugar, ela é ligada a um princípio de gênese independente de uma regra de semelhança. Ou seja, a lógica da identidade não dá conta desse domínio e, contra esta, Deleuze aposta na lógica da diferença para pensar os processos de encarnação e especificação dos organismos:

Pode acontecer, então, que a estrutura renasça em nível totalmente distinto, por outros meios, com uma determinação inteiramente nova de elementos diferenciais e de ligações ideais. É o caso da Genética. ${ }^{14}$

Para pensar o processo de diferenciação, Deleuze lança mão de um complexo conjunto de conceitos - como as noções de virtual, multiplicidade, estrutura e Ideia. Sem entrar nestes méritos, gostaríamos de enfatizar como o nível molecular dos genes se alinha à lógica diferencial ao menos de três maneiras. Primeiro, na medida em que ele é irredutível a

12 GUALANDI, Deleure, p. 20.

${ }^{13}$ LAPOUJADE, Deleuze, os movimentos aberrantes, p. 59.

${ }^{14}$ DELEUZE, Diferença e Repetição, p. 264. 
indivíduos, representantes, gêneros ou espécies delimitadas. Ao mesmo tempo, e em segundo lugar, ele não se confunde com uma zona meramente indeterminada, mas é o fundo que constitui e ameaça os organismos, isto é, tanto princípio de gênese quanto de dissolução. Por fim, em contraposição ao modelo hierárquico platônico, o domínio do molecular é um exemplo literal do valor igualitário do ser unívoco: nele, as fronteiras entre homens, animais e plantas são embaralhadas e postas em um plano horizontal.

Pois bem, podemos nos perguntar: quais as implicações da lógica da diferença em biologia para a questão política das identidades?

Peguemos como primeiro exemplo o conceito deleuziano de "homossexualidade molecular". Além de desenvolvê-lo em Proust e os Signos (1976) e em O Anti-Édipo (1972), o próprio Deleuze - monogamicamente casado com uma mulher - se colocava na cena pública como um "homossexual molecular". Como Beatriz Preciado nos lembra, tal posição levou a desconfiarem da verdade filosófica e política do seu discurso:

Michel Cressole, jovem jornalista de esquerda no Libération, bicha e amigo/inimigo pessoal de Deleuze, será o primeiro a duvidar da verdade, filosófica e política, de um discurso sobre as drogas, a esquizofrenia ou a homossexualidade que não conhece a dependência, a doença mental ou a fecalidade. ${ }^{15}$

$\mathrm{Na}$ sua Carta a um crítico severo, respondendo a Cressole, Deleuze retoma a distinção conceitual entre dois tipos de homossexualidade: uma global e uma molecular. Junto à análise de Preciado, acompanhemos mais de perto a distinção deleuziana.

No primeiro caso, o problema da homossexualidade consiste na delimitação de um grupo exclusivo, de suas opções e predicados determinados. A homossexualidade se define aqui conforme a lógica da representação e da identidade, ou seja, através da especificação que separa feminino e masculino, heterossexual e homossexual. ${ }^{16}$ A homossexualidade molecular, por outro lado, remete a um plano além e aquém das distinções precedentes. Este configura não só a condição originária das distinções de gênero e de sexo, como também revela que - queira ou não - todo indivíduo é atravessado por relações tanto hétero quanto homossexuais, tanto femininas quanto masculinas. No nível cromossomático, testemunhamos uma indistinção de base que subverte toda especificação sedentária e hierárquica. Em termos deleuzianos, ao invés de uma identificação restrita de gênero ou sexo, afirma-se o retorno incessante do que difere. ${ }^{17}$

15 PRECIADO, "Da filosofia como modo superior de dar o cu”, Manifesto contrassexual, p. 175.

${ }^{16}$ Ibid. p. 186.

${ }^{17}$ Lê-se em $O$ Anti-Édipo: “o homem é apenas aquele em que a parte masculina domina estatisticamente, e a mulher, aquela em que a parte feminina domina estatisticamente. E assim, no nível das combinações elementares, é preciso fazer intervir pelo menos dois homens e duas mulheres para constituir a multiplicidade na qual se estabelecem comunicações transversais, conexões de objetos parciais e fluxos: a parte masculina de um homem pode comunicar com a parte feminina de uma mulher, mas também com a parte masculina de uma mulher, ou com a parte feminina de um outro homem, ou ainda com a parte masculina de um outro homem etc.” (DELEUZE E GUATTARI, O Anti-Édipo, p. 97). 
Para Deleuze, a perspectiva molecular não pertence à ordem do indivíduo, propriedade, comunidade ou grupo, mas a uma ordem de relações transversais. ${ }^{18}$ Por conta disso, a natureza do problema da determinação difere daquela da homossexualidade global. Se neste último caso interessa determinar um lugar de fala, agora trata-se de buscar as operações que permitem afirmar a homossexualidade como posição de enunciação universal. Com isso, resume Preciado, a resposta a Cressole consiste em dizer: "O problema da filosofia, dirá Deleuze, não é tanto determinar quem pode pensar ou falar sobre o que, e sim como criar um conjunto de condições que permitiriam a todos e a cada um falar" ${ }^{\prime 1}$.

Tudo levado em conta, a filosofia da diferença termina adotando uma postura crítica quanto às questões identitárias. Se afirmar a identidade significa delimitar um grupo exclusivo, suas opções e predicados próprios, afirmar a diferença significaria, ao contrário, dissolver fronteiras e hierarquias ao invés de reafirmá-las. Em consonância com a intuição do ser unívoco, trata-se de fazer retornar um igualitarismo radical contra todo tipo de fundamento excludente. Assim como na formulação provocativa de Preciado - em que Deleuze proporia em filosofia um "modo superior de dar o cu" para a questão da homossexualidade -, para as questões identitárias, como princípio geral, a filosofia da diferença oporia um modo superior de igualdade.

Sem dúvidas, esta é uma das maneiras - e talvez a mais comum entre elas - de relacionar a filosofia da diferença com a questão política das identidades. Em suma, opomos a transversalidade do mundo das diferenças ao segmentarismo das identidades. De forma análoga, poderíamos deslocar o mesmo raciocínio de Deleuze sobre a homossexualidade para outros domínios, bem como para outros conceitos - Mil Platôs (1980) é vasto de exemplos, como devir-mulher, rizoma e linha de fuga, para ficar apenas em três. Como última análise de caso, consideremos a relação entre raça, genética e identidades políticas.

No decorrer da segunda metade do século XX, as possibilidades abertas pela genética criaram toda uma tradição de estudos sobre a variabilidade biológica humana. Por exemplo, nos anos 90 surge o Human Genome Diversity Project (HGDP), projeto dedicado a estudos comparativos sobre diversidade genômica. ${ }^{20}$ No horizonte político desta e de outras iniciativas, encontra-se a aposta na biologia como forma de combate ao racismo. A lógica é a seguinte: da perspectiva molecular, as classificações e hierarquias raciais caem por terra, pois o código genético humano revela-se igualmente diverso (independente de características anatômicas e de origem). Nesse sentido, a biologia constitui-se como prova científica da diversidade da condição humana e, não por outra razão, ela pode ser mobilizada contra critérios raciais de discriminação.

Um caso didático é o do artigo "Retrato Molecular do Brasil", publicado no ano 2004. Através do sequenciamento de porções do DNA mitocondrial e cromossomo Y,

${ }^{18}$ DELEUZE, Carta a um crítico severo, Conversações, p. 21: “O problema nunca consistiu na natureza deste ou daquele grupo exclusivo, mas nas relações transversais em que os efeitos produzidos por tal ou qual coisa (homossexualismo, droga, etc.) sempre podem ser produqidos por outros meios."

19 PRECIADO, "Da filosofia como modo superior de dar o cu", Manifesto contrassexual, p. 186. Mesma fórmula que Deleuze aplica à literatura: "Fim último da literatura: por em evidencia no delírio essa criação de uma saúde, ou essa invenção de um povo, isto é, uma possibilidade de vida. Escrever por esse povo que falta... ('por' significa 'em intenção de' e não 'em lugar de')." (DELEUZE, “A literatura e a vida”, Crítica e Clínica, p. 15).

${ }^{20}$ https://www.hagsc.org/hgdp/ 
cientistas brasileiros concluíram que as "pessoas brancas" analisadas no estudo possuíam uma variabilidade genética tão ligada às populações ameríndias e africanas quanto às europeias. Dada toda a história colonial brasileira, esse resultado teria implicações políticas para a luta contra o racismo. Como afirmam os cientistas:

O Brasil certamente não é uma "democracia racial". Prova disso é a necessidade de uma lei para proibir o racismo. Pode ser ingênuo de nossa parte, mas gostaríamos de acreditar que se os muitos brancos brasileiros que têm DNA mitocondrial ameríndio ou africano se conscientizassem disso valorizariam mais a exuberante diversidade genética do nosso povo e, quem sabe, construiriam no século 21 uma sociedade mais justa e harmônica. ${ }^{21}$

Não é difícil enxergar uma afinidade com a filosofia da diferença. Embora Deleuze nunca tenha se dedicado diretamente ao problema da variabilidade genética e suas implicações para o racismo, nada impede uma extrapolação do seu raciocínio para este ambiente. Poderíamos opor um conceito global de raça a um conceito molecular e, respectivamente, distinguir duas maneiras de determinar o problema. Por um lado, na visão global a questão racial passa pela representação de indivíduos, grupos e seus respectivos lugares de fala. Por outro, molecular e filosoficamente falando, o problema é antes o de definir as operações lógicas que permitem afirmar a variabilidade genética como posição universal. Opõe-se, com isso, um igualitarismo radical ao modelo discriminatório da representação. Pautada em uma igualdade ontológica, a filosofia da diferença apresentaria a necessidade da superação do conceito de raça e da lógica da identidade que o sustenta.

\section{RECALIBRAGEM: DIFERENÇA E RAZÃO NEGRA}

Em Crítica da Razão Negra (2013), Achille Mbembe empreende uma crítica da modernidade tendo como centro a questão da raça e do racismo. Ao nosso ver, suas reflexões podem ser diretamente confrontadas com a filosofia da diferença.

Para Mbembe, o conceito de raça não deve ser entendido como um fato natural físico, antropológico ou genético. Apenas a partir do século XVIII que ele se vincularia mais fortemente com discursos de verdade. Em sua origem moderna, porém, a raça era antes de tudo uma "ficção útil"22. A expansão transatlântica liderada por Portugal e Espanha a partir do século XIV, é sabido, teve como condição a exploração de povos africanos. Nesse sentido, os empreendimentos coloniais foram acompanhados de uma intensa "fabulação" em relação ao negro e à África. Motivados pelas novas dinâmicas do capitalismo nascente, os europeus projetavam nos povos africanos a figura do dessemelhante, da diferença e do negativo. Dessa forma, em nome da missão "civilizatória" do colonialismo, podiam instrumentalizá-los para o desenvolvimento comercial e para a expansão territorial.

${ }^{21}$ PENA et al., "Retrato molecular do Brasil", p. 25.

22 MBEMBE, Crítica da razão negra, p. 29. 
A transnacionalização da condição negra levanta um paradoxo: em paralelo à expansão europeia no mundo, ocorre uma retração de sua imaginação cultural e histórica. Corresponde ao processo de fabulação o que Mbembe chama de "clausura do espírito" europeu. ${ }^{23} \mathrm{Nem}$ o impulso iluminista para as ciências e para a razão mudou esse quadro. Segundo Mbembe, quando se trata do negro e da África, o comprometimento com critérios objetivos de verdade some do olhar europeu. Por exemplo, Buffon em Variétés de l'espèce bumaine (1749) classifica as raças baseado em preconceitos ingênuos e sensualistas. O negro é então caricaturado como uma figura pré-humana, degradada, reduzido a animalidade e sensações. O mesmo valeria para Hegel em seu $A$ Raz̧ão na História (1837). O reducionismo europeu alcança o ápice, finalmente, na biologização da raça no século XIX, de onde lançamse as bases das teorias do racismo científico, do darwinismo social e do eugenismo.

É verdade, o mundo pós-segunda guerra se contrapõe por toda parte aos fundamentos do racismo. Como vimos de exemplo, a emergência da genética põe em questão a interpretação biológica das distinções entre grupos humanos. Os estudos em variabilidade genômica apontavam, assim, para um horizonte pós-racial de humanidade. De acordo com Mbembe, porém, postos do avesso, o fim do século XX e a virada no novo século representam uma recalibragem do racismo. Ao invés de dar o seu ponto final, a ciência genômica faz emergir um novo pensamento da raça:

Quer se trate da exploração das bases genômicas das doenças que acometem determinados grupos ou do rastreamento das raízes ou das origens geográficas dos indivíduos, o recurso à genética tende a confirmar as tipologias raciais do século XIX (branco caucasiano, negro africano, amarelo asiático). ${ }^{24}$

Mbembe enumera vários fatores ligados à reativação da lógica racial. A transformação do modo de produção capitalista, o fortalecimento da ideologia de segurança e a reconfiguração das esferas de informação, por exemplo, fazem com que processos de diferenciação, classificação e hierarquização para fins de exclusão e controle sejam recuperados por todos os lados. Mesmo assim, poderíamos perguntar: como um conceito tão ultrapassado quanto o de raça continua servindo como princípio de divisão social? O que frustra as expectativas depositadas na genética?

A resposta de Mbembe coloca um dado fundamental para nosso problema. Se a "razão negra" não está comprometida com um fato natural genético, também a negação da essencialidade da raça não implica o fim do racismo. O caráter ficcional do conceito de raça não faz dele destituído de realidade. Ao contrário, se a razão negra forma uma estrutura imaginária que escapa dos limites do real, é justamente para produzir nele "duplos", "simulacros", "equivalentes" e "máscaras" com força de organização do mundo empírico e psicológico. ${ }^{25}$ Noutros termos, o dualismo essência/aparência não é suficiente para pensar as dinâmicas da razão negra. Em rigor, precisamos recorrer a certa lógica transcendental.

23 Ibid. p. 41.

24 Ibid. p. 48.

25 Ibid. p. 69. 
Desta perspectiva, mesmo sem essencialidade as aparências continuam a produzir realidade e verdade segundo os princípios que as condicionam. Pode-se dizer, então, que as teorias biologizantes e essencialistas da raça não são simples equívoco científico, mas, antes de mais nada, efeito da fabulação e clausura que as condicionam.

A fabulação orienta-se para um fim preciso: fabricar o excedente, isto é, fabricar uma espécie de vida que pode ser instrumentalizada e dispendida sem reservas. A criação do sujeito racial vem para responder essa demanda e, não o bastante, precisamente este fim que continua a ser mobilizada no mundo contemporâneo. Assim, Mbembe pode concluir sobre a raça:

Pouco importa que ela não exista enquanto tal, e não só devido à extraordinária homogeneidade genética dos seres humanos. Ela continua a produzir efeitos de mutilação, porque originariamente é e será sempre aquilo em cujo nome se operam cesuras no seio da sociedade. ${ }^{26}$

Enquanto negação do fundamento de discriminações, como vimos, a filosofia da diferença opõe às identidades a lógica de uma igualdade radical entre os seres. A partir da reflexão de Mbembe, contudo, podemos problematizar tal posição. No quesito raça, e esta é nossa hipótese, a recalibragem do racismo incide tanto sobre o pensamento genômico quanto sobre a ontologia do ser unívoco. Enquanto estrutura histórica, social e imaginária do real, o conceito de raça não precisa de um fundamento para produzir efeitos sobre o mundo. Por mais que a biologia molecular testemunhe uma diversidade irredutível da natureza humana, o mundo fenomênico continua a ser organizado, distribuído, e repartido ao longo de hierarquias racialmente determinadas; por mais que a lógica da identidade seja deslegitimada, o pensamento ocidental continua fabulador e enclausurado quando se trata da questão racial.

Ao desconsiderar a dinâmica da razão negra dentro do capitalismo, a filosofia da diferença erraria o alvo. Mais do que isso, à revelia do seu suposto progressismo, ela corre o risco de converter-se em desvio retórico da questão política das identidades raciais. Para explicitar este último ponto, voltemos mais uma vez para o artigo "Retrato Molecular do Brasil".

\section{FILOSOFIA DA DIFERENÇAE IDEOLOGIA PÓS-RACIAL}

Ao abordar a questão da recalibragem do racismo no pensamento genômico, Mbembe cita o artigo crítico de Ricardo Ventura Santos e Marcos Chor Maio, Race, Genomics, Identities and Politics in Contemporary Brazil (2004). Nele os autores lidam com o estudo da origem genética dos brasileiros, mas sob a luz mais ampla da contexto histórico-social do racismo nacional. Para Santos e Maio, o tema da miscigenação é incontornável ao pensar o racismo em sociedades multirraciais. Do lado da sociologia brasileira, podemos situar a questão a partir de três perspectivas.

Com o protagonismo de Silvio Romero, as últimas décadas do século XIX sustentaram o paradigma racial. Desta visão, a miscigenação da população brasileira é um fato

${ }^{26}$ Ibid. p. 73. 
social insuperável. A promoção da coesão social, no entanto, depende que a mistura racial seja organizada segundo um princípio de seleção natural. Com o cruzamento preferencial de negros e mestiços com brancos, tenderíamos ao embranquecimento da população brasileira no fim de "um longo processo de fusão e seleção racial, no qual, dada sua 'superioridade' física e mental, brancos triunfariam" 27.

Contra as teorias do embranquecimento, as décadas de vinte e trinta viram nascer o paradigma cultural. Com o clássico de Gilberto Freyre, Casa Grande e Senzala (1933), a miscigenação ganha novo sentido para a formação da nação brasileira. Freyre defende que as relações entre a "casa grande" e a "senzala" era de uma "tensa mas balançada coexistência da perversidade dos senhores e sua intimidade com o escravo" 28 . Lado "bom" da escravidão: no contato íntimo entre senhores e escravos, o povo brasileiro formou uma identidade singular que embebedou-se da mistura racial. Assim, ao contrário dos EUA ou da África do Sul onde o racismo se manteve operante, no Brasil as cisões por cor teriam se diluído na relativa natureza democrática da cultura brasileira.

A partir dos anos cinquenta, as teses de Freyre perderiam força. Com Florestan Fernandes, surge o paradigma social e estrutural. Em seus estudos, Florestan demonstra como, a despeito da teoria da miscigenação, com o fim da escravidão houve persistência do prejuízo racial. A transição da sociedade de castas para a sociedade de classes nunca foi realmente completa e, não por outra razão, falar em "democracia racial" serve apenas para camuflar as desigualdades raciais que continuam operando no presente. ${ }^{29}$ Graças a isso, a ideologia liberal pôde operar uma cruel inversão: de vítima, a população negra passa a ser a culpada pela própria miséria econômica. Apesar de divergências quanto às soluções propostas por Florestan, desde então a sociologia crítica teve como desafio o "mito da democracia racial" em seu horizonte.

Retrato Molecular do Brasil relaciona os padrões da análise genômica com a história da formação do povo brasileiro. Seus resultados indicam no homem branco, explicitam Santos e Maio, "linhagem europeia paterna predominante verificada através do cromossomo Y e linhagem africana e ameríndia materna verificada através do DNA mitochondrial" ${ }^{30}$. No fim das contas, nos dizem:

Em termos de resultado, o que emerge de "Retrato Molecular do Brasil" é a corroboração (...) da natureza miscigenada da amostra de auto-declarados brasileiros brancos, dado que a maioria (aproximadamente 60\%) da linhagem materna é de origem ameríndia e africana. ${ }^{31}$

Bem recebido pela mídia e opinião pública, o artigo dos geneticistas foi duramente criticado por certos segmentos sociais e, em especial, Santos e Maio seguem o argumento de

27 SANTOS \& MAIO, "Race, Genomics, Identities and Politics in Contemporary Brazill", p.353, tradução nossa.

28 Ibid. p.353.

29 Ibid. p. 354.

30 Ibid. p. 362.

31 Ibid. p.362. 
Athayde Motta. Segundo o militante e pensador negro, Retrato Molecular do Brasil se conforma com uma interpretação anacrônica da sociedade brasileira, a saber, o paradigma cultural representado por Gilberto Freyre. Além disso, ao relacionarem a genética com o tema das identidades políticas, os cientistas pressupõem que a herança biológica de nível molecular é suficiente para igualar uma pessoa branca com uma negra. Por fim, e mais importante, é preciso levar em conta o impacto dos resultados genéticos na implementação de políticas públicas anti-racistas. Isso porque, citam Athayde, "a pesquisa apresenta um simulacro de suporte científico para o mito da 'democracia Racial"' 32.

Athayde desloca os estudos em variabilidade genética para questões políticas muito concretas. No Brasil e em muitos outros países, a luta anti-racista se faz pela afirmação da identidade racial. Por um lado, esta é uma estratégia que visa combater o mito da democracia racial e a suposta igualdade de condições que ele sustenta. Por outro lado, esta é uma maneira de produzir políticas de discriminação positiva, como por exemplo as cotas raciais para o ingresso nas universidades. A dissolução de todo e qualquer critério de discriminação, todavia, dinamita o debate. Do ponto de vista genético, mesmo uma pessoa auto-declarada branca poderia se reivindicar indígena ou negra. Dessa forma, Retrado Molecular do Brasil

é visto como politicamente conservador, na medida em que evita transformar relações estruturais de desigualdade racial no Brasil, um processo que envolveria necessariamente o embate (no nível político) de premissas identitárias ao longo das linhas propostas pelo movimento negro. ${ }^{33}$

Em certo sentido, a crítica contra Retrato Molecular do Brasil está afinada com o argumento da "verdade da aparência" de Mbembe: a determinação da raça e do racismo se faz por estruturas de nível social e histórico, independente do seu suporte ontológico e biológico. Ao ignorarmos este dado fundamental, a negação dos fundamentos da discriminação racial como estratégia antirracista tem o efeito contrário do esperado. Por vezes sem o saber, ela apenas reafirma o valor positivo depositado na miscigenação e suas mistificações. Analogamente, abstraída da retificação crítica da razão negra, a mera aplicação da filosofia da diferença em territórios pós-coloniais reproduz o mesmo juízo de valor. Parafraseando Athayde, sua operação lógica traria apenas um "simulacro de suporte filosófico" para o mito da democracia racial. Do ponto de vista pós-colonial, portanto, a aposta na filosofia como porta-voz refinado de uma igualdade superior não passaria de mais um apêndice da razão negra, a saber, a versão pós-racial da ideologia racista.

Com boas razões, poderíamos contra-argumentar que a filosofia deleuziana não só permite como exige que seus conceitos sejam moldados segundo o caso em que se aplicam. Conforme a terminologia que adotamos neste artigo, a filosofia da diferença não se reduz ao pensamento nem do indiferenciado nem do diferenciado, mas privilegia os processos de diferenciação, nunca dados de antemão ou concluídos definitivamente. Esta perspectiva poderia ser mobilizada com bons frutos, por exemplo, para pensar as diferenciações raciais

32 Ibid. p. 366.

33 Ibid. p. 368. 
(seus devires) em sua multiplicidade própria, isto é, sem reduzi-las a uma lógica essencialista, e mesmo subvertendo esta última.

Não se trata aqui, pois, de ignorar outras perspectivas ou de atacar um "espantalho" de Deleuze. Também com boas razões, ao menos foi o que tentamos demonstrar, a filosofia deleuziana comporta extrapolações nem tão produtivas. A mera importação de seu pensamento, abstraída de uma consideração mais apurada de cunho sócio-histórico, pode converter-se em apagamento das desigualdades racialmente determinadas. E se esse risco não é banal, é na estrita medida em que a ausência de uma reflexão sistemática sobre a temática racial no pensamento de Deleuze é, ela mesma, o que torna essa possibilidade sempre latente.

Sabe-se que o silêncio é uma das operações mais sutis e perversas em sociedades estruturalmente racistas. Com efeito, desdobrar a filosofia contra o racismo deveria passar, em primeiro lugar, por uma reflexão sobre a raça em toda sua complexidade histórica e social, assunto que se trata de abordar por fim.

\section{CONSIDERAÇÕES FINAIS}

Procuramos demonstrar que sem um reajuste histórico-social de suas premissas a filosofia da diferença abre margens para "aplicações” duvidosas quanto à questão política da identidade racial. Ao invés de descartá-la, contudo, talvez seja mais interessante descolonizála, isto é, romper sua clausura e recuperar seu espírito sob novas coordenadas.

Em conclusão, propomos algumas direções de pesquisa a serem exploradas. De maneira geral, podemos esboçar duas afinidades parciais entre a "Crítica da Razão Negra" de Mbembe e a "filosofia da diferença" de Deleuze. Como projeto negativo, ambos buscam colocar do avesso as estruturas do imaginário ocidental que redundam na condenação da diferença. De sua parte, Deleuze faz a denúncia do fundo platônico da filosofia. Mais profundamente, no entanto, Mbembe traz à tona a centralidade da raça como forma histórica da exclusão no capitalismo moderno. Em seus projetos positivos, ao que parece, os dois também estão parcialmente sintonizados: em última análise, a requalificação da diferença deve ser orientada pelo horizonte de uma igualdade radical entre os seres. Para evitar a simples inversão dos polos da opressão, Mbembe não deixa de enfatizar uma igualdade que seja pautada na diversidade concreta do mundo. ${ }^{34}$ Entretanto, e é aqui que ele se afasta de Deleuze, para não cairmos em um discurso ideológico é preciso somar a retificação crítica da razão negra.

Se estivermos corretos, sob a luz destas novas coordenadas, o diagnóstico crítico da filosofia da diferença se inverteria. Em casos como o brasileiro, ao invés de se opor, a

34 “O que precisamos imaginar é uma política do humano que seja, fundamentalmente, uma política do semelhante, mas num contexto em que, cabe admitir, o que partilhamos logo de início são as diferenças. E são elas que, paradoxalmente, precisamos pôr em comum" (MBEMBE, Crítica da rąãa negra, p. 307). Ou então: "Mas, como se vê em parte da crítica da Razão negra moderna, a proclamação da diferença é somente um momento num projeto mais amplo - o projeto de um mundo por vir, de um mundo a nossa frente, cuja destinação é universal, um mundo livre do fardo da raça e livre do ressentimento e do desejo de vingança que toda e qualquer situação do racismo suscita" (Ibid., p. 315). 
afirmação da identidade negra faz coro com o horizonte concreto de uma igualdade pósracial.

\section{PHILOSOPHY OF DIFFERENCE AND THE POLITICAL QUESTION OF RACIAL IDENTITY}

Abstract: This article investigates the relation between Gilles Deleuze's philosophy of difference and the political question of racial identity. At first, we developed the critique of the philosophy of difference in biology to the concept of race. Then, based on Achille Mbembe, we demonstrate how phenomena of the contemporary world, in spite of the denial of biological grounds of discrimination, are reorganized along racially determined hierarchies. From here on, in the particular case of Brazil, we argue that the bet on philosophy as a spokesman for a superior equality, without knowing and absent, translates a regressive political position, that is, induces the reaffirmation of the positive value deposited in the myth of racial democracy. Finally, we seek to point out the initial directions for a readjustment of the relations of the philosophy of difference to the racial question.

Keywords: difference - identity - race - Deleuze - Mbembe.

\section{REFERÊNCIAS BIBLIOGRÁFICAS}

BADIOU, A. Deleuze - O clamor do Ser. Tradução de Lucy Magalhães. Rio de Janeiro: Zahar, 1997.

DELEUZE, G., Diferença e Repetição. Tradução de Luis B. L. Orlandi e Roberto Machado, Rio de Janeiro, Graal, 2006.

. Crítica e Clinica. Tradução de Peter Pál Pelbart. São Paulo: editora 34, 1997.

. Conversações. Tradução de Peter Pál Pelbart. São Paulo: editora 34, 1992.

DELEUZE, G. e GUATTARI, F., O Anti-Édipo. Tradução de Luis B. L. Orlandi. São Paulo: Editora 34, 2010.

GUALANDI, A., Deleuze. Tradução de Danielle Ortiz Blanchard. São Paulo: Editora Estação Liberdade, 2003.

LAPOUjADE, D., Deleuze, os movimentos aberrantes. Tradução de Laymert Garcia dos Santos. São Paulo: n-1 edições, 2015.

MBEMBE, A. Crítica da Rą̧ão Negra. Tradução de Sebastião Nascimento. São Paulo: n-1 edições, 2018.

PRECIADO, B. Manifesto contrassexual. Tradução de Maria Paula Gurgel Ribeiro. São Paulo: n-1 edições, 2015. 
PENA, S.D.J., D.R. CARVALHO-SILVA, J. ALVES-SILVA, V.F. PRADO, F.R SANTOS, Retrato molecular do Brasil, in: Ciência Hoje 159, 2000, pp. 16-25.

SANTOS, R. V. e MAIO, M. C. "Race, Genomics, Identities and Politics in Contemporary Brasil", in: Critique of Anthropology 24, $\mathrm{n}^{\circ}$ 4, 2004, pp. 347-378. Versão online: http://coa.sagepub.com/cgi/content/abstract/24/4/347 